"La fin du pillage des auteurs": Louvigny de Montigny's International Press Campaign for Authors' Rights in Canada

Shelley S. Beal ${ }^{1}$

The legal precedent establishing the 1886 International Berne Convention on Intellectual Property as Canada's predominant copyright legislation was the result of Mary vs. Hubert, a civil suit tried in Quebec Superior Court on 23 March 1906. Deciding in favour of the Parisian author Jules Mary, Judge Thomas Fortin ruled that the International Copyright Act of I886, the Imperial law that brought Great Britain and its Commonwealth members into the Berne Convention, took precedence over the 1875 Canadian Act Respecting Copyright in the matter of artistic works originating in Berne member countries. This victory for the rights of foreign authors would gradually, but effectively, bring the practice of literary piracy to a close in Canada. The elimination of such unfair competition would stabilize relations in both publishing and bookselling and prepare the way for a more professional and international industry in the twentieth century. Ironically, the dependence on foreign authors' works was reduced as a result of Mary vs. Hubert; this allowed Canadian authors to thrive, ever more successfully, in their own marketplace and abroad. The defendant in the suit, Montreal publisher Barthélémy Hubert, was ordered to halt distribution of his edition of Mary's I892 novel, Tante berceuse. A precedent was set for the payment of royalties, by publishers and theatre producers, to eligible foreign authors and playwrights (from Berne member nations); also, the sale of authorized editions of members' works would be protected from unfair competition in the form of unauthorized reprints, or "pirated" versions.

I Shelley Beal is a $\mathrm{PhD}$ candidate at the University of Toronto who has done all of her graduate research and coursework within the Collaborative Program in Book History and Print Culture. Her doctoral dissertation will explore the contributions made by Theodore Stanton - an American journalist, foreign editor, and literary agent in Paris around 1900 - to French-American cultural rapprochement, based on Stanton's press articles and the collection of his papers. 
Since 1886 , the Canadian law of 1875 had run concurrently with the Imperial law until the present domestic Copyright Act of 192I came into effect with royal assent in 1924. (Canada agreed to join the International Convention under its own name at the Rome Convention of 1928 but did not apply the law until 1931.) The successful outcome for the plaintiff in Mary vs. Hubert was the result of years of information gathering and an intensive public awareness campaign waged in a variety of periodicals on both sides of the Atlantic by Louvigny de Montigny of Montreal and his colleagues in the Association de secours mutuels des journalistes canadiens-français. De Montigny and the Association des journalistes canadiens-français (AJCF) not only persuaded authors in France to mount a test case in Canada, they shepherded the challenge through Canadian legal firms and the court.

Gordon Roper and George L. Parker have each described with great precision and authority the complicated triangle between Great Britain, Canada, and the U.S. that turned Canada into a copyright "battleground" in the late nineteenth century. ${ }^{2}$ Parker wrote, however, from the perspective of English-language publishing when he maintained that "the flood of pirated reprints dried up" in Canada by the end of the century, after the United States resisted joining the Berne Convention but passed the Chace Act in I89I and entered into a reciprocal agreement on copyright with Great Britain. ${ }^{3}$ In a paragraph outlining the conditions related to book prices that prevailed in French-Canadian publishing and bookselling firms, Parker records the persistence of literary piracy in Quebec and indicates that the lack of a challenge by authors in France was the reason why Mary vs. Hubert was still necessary almost twenty years after the Berne Convention became law in the Dominion of Canada (227).

In Quebec and other French-speaking markets prior to 1906, the wilful misperception, on the part of publishers and booksellers, of ambiguity in the two concurrent laws, coupled with the fact that tariff amendments to the Canadian Act favoured protectionist EnglishCanadian book-trade interests while disregarding the consequences for French-Canadian producers and readers, allowed the practice of literary piracy, or the "pillaging" of foreign literary works, to persist

2 See Gordon Roper, "Mark Twain and His Canadian Publishers: A Second Look," The Papers/Cahiers 5 (1966): 30-89, and George L. Parker, The Beginnings of the Book Trade in Canada (Toronto: University of Toronto Press, 1985), 167-256.

3 Parker 2II. 
long enough in the French-Canadian market to warrant the court challenge. (The historically correct and geographically inclusive term "French-Canadian" is retained here in preference to "Québécois.") Both English- and French-Canadian publishers, typesetters, printers, binders, and booksellers preferred to adhere to the Canadian law and remained skeptical of the validity of the "Swiss convention," maintaining that the Berne agreement only guaranteed foreign artistic producers the right to apply for the same rights as Canadians under the domestic law, which required the registration of a given work in Ottawa, and more importantly, its "manufacture" in Canada. Under the Berne agreement adopted into Imperial law, however, creators from signatory nations were, and still are, automatically protected in all other member states upon the normal registration of their works at home. British authors were already guaranteed copyright protection in Canada, because no Canadian law could have been ratified without this provision, but literary works from France had no more status under the Canadian Act than those of all other, legitimately foreign, cultures.

Jacques Michon has also acknowledged de Montigny's role in the 1906 victory and described the frustrating conditions under which contemporary Montreal publishers were forced to operate. ${ }^{4}$ Michon's reference to the transatlantic press campaign piqued a bibliographical interest in assembling a corpus of these articles. The resulting compilation, which includes some seventy photocopied pieces of varying length and tone, is astonishing for the breadth and depth of its coverage, not only of the pre-1906 copyright and tariff difficulties in French Canada, but of the AJCF's creation and of the press campaign itself. This small archive is the subject of an ongoing collaboration between this author, at the Joseph Sablé Centre for $19^{\text {th }}{ }^{-C}$ entury French Studies at the University of Toronto, and researchers at the Groupe de recherche sur l'édition littéraire au Québec (GRÉLQ), Université de Sherbrooke. This article is intended to shed some light on the disparity between the two Canadian book markets under the domination of a single Canadian Copyright Act before 1906. In

4 See Jacques Michon (with Sylvie Faure), Appendix 3, "L'Association des journalistes canadiens-français et le droit d'auteur," in Histoire de l'édition littéraire au Québec au XXe siècle, volume 1: La naissance de l'éditeur Igoo-1939 (Montreal: Fides, 1999), 406-09, and also Michon, Appendix 8, "Les Romans contrefaits: Entrevue de Louvigny de Montigny avec Etienne Roby," 422-24 in the same volume. 
presenting de Montigny's press campaign, it is hoped that the wealth of contemporary information the pieces contain will amplify the existing record and show an instance where the two solitudes of our national publishing histories not only intersected, but interacted. ${ }^{5}$ It will be seen that many of the problems regarding importation and reprinting that the Montreal publishers continued to face well after I886 and I89I were a direct result of the political influence of Toronto publishers on federal tariff and copyright law, and hinged on different English and French traditions in book production.

Book historians will recognize the link between the material form of books and the legal and market conditions governing their production and distribution. Indeed, the physical book is at the root of British and Canadian copyright laws. Prior to the Berne agreement, copyright did not mean the absolute ownership of intellectual property by its creator in the way that it is understood today; copyright, as the name suggests, referred to monetary rights to a particular published text. Copyright was held by the publisher, often in agreement with the author, but not by the author alone. It worked well enough within national confines under statutory law. The Berne Convention marks an important shift towards the notion of creative and professional control that artistic producers still defend today under Berne, now a treaty administered by the World Intellectual Property Organization (WIPO); it legitimized nineteenth-century authors in the increasingly globalized business of publishing and prepared the way for authors' associations and their professional partners such as literary agents and publicists.

Louvigny de Montigny and the Association des journalistes canadiens-français

Born in 1876 in Saint-Jérôme, Quebec, de Montigny received a law degree from Université Laval, situated at the time in Montreal. The young de Montigny was a poet, publishing his first poems in Montreal newspapers at the age of eighteen, under the pseudonym of Carolus Glatigny. He was one of the founding members of the École littéraire de Montréal in 1895 and later started and edited two newspapers, the liberal Les Débats in 1900, and the Gazette municipale de Montréal

5 'The History of the Book in Canada / L'histoire du livre et de l'imprimé au Canada" project goes a long way toward bridging the historiographical gap: See $<$ http://www.hbic.library.utoronto.ca/>. 
in 1904, the official bilingual organ of the City of Montreal. From I910 until his death in 1955, de Montigny was the principal translator for the Canadian Senate, putting the combination of his language skills and his legal training at the service of the legislative body in Ottawa. He continued his activities as a sometime author, editor, and publisher: in 1916, he introduced the beloved novel Maria Chapdelaine to Canadian readers. De Montigny's lifelong interest in the quality of the French language in Canada, the subject of his own 1916 book, La langue française au Canada: son état actuel, was already in evidence in his 1903 play Les boules de neige, which provoked discussion of the use of popular speech in literary works. The French Academy's acclaim in 1937 for his novel, La revanche de Maria Chapdelaine, is one of de Montigny's literary and official honours. He was Officer of Public Instruction for the Royal Society of Canada and was named Chevalier de la légion d'honneur (France) in 1925. His ardent defence of authors' rights did not cease in 1906. From 1922, he served for over 30 years as the Canadian representative of the Sociéte des gens de lettres de France (the French Authors' Society). The main collection of Louvigny de Montigny's papers is held at Library and Archives Canada, still awaiting the biographer of this somewhat overlooked cultural activist and man of letters.

The Association des journalistes canadiens-français (AJCF) was formed in Montreal in late 1903. Its stated goal was to elevate the profession and to preserve and strengthen the presence of French culture in North America by uniting journalists from all FrancoAmerican communities in a fight against specific threats to their shared heritage. ${ }^{6}$ The challenges in question were primarily the problem of literary piracy, or so it would seem, as the AJCF's operations ceased after the Mary vs. Hubert judgment in 1906. Louvigny de Montigny played a major part in founding the AJCF and headed its Committee on Authors' Rights. Josée Vincent has written widely on literary professional associations: she provides a detailed account and analysis of the founding of the Sociéte des écrivains canadiens by many former AJCF members in 1921, the Frenchlanguage section of the Canadian Authors' Association that had been

6 The power of the press was evoked by P. Arthur Côté of La Presse at the AJCF's first banquet: "Les 'reporters' sont les historiens modernes," La Presse, 9 Dec. 1903: $\mathrm{r}$. 
formed shortly beforehand. ${ }^{7}$ Its predecessor, the Canadian Society of Authors, had been formed in Toronto in 1899 in order to have a voice in the reform of domestic copyright law then being proposed by publishers. ${ }^{8}$ Although the first Canadian Society lasted some ten years, it had no mandate to address the different set of problems facing authors in French Canada, although it supported the Berne Convention in principle. In Montreal, it was the journalists who got together to rise to the defence of authors. This may be explained by the fact that a) French-Canadian authors were still very few in number, b) journalists worked within a more established, localized network of peers and were simply better disposed to organization, and c) the investigative and political nature of the AJCF's mandate was perhaps better suited to the journalist's temperament and range of concerns. This last observation must be tempered by the fact that de Montigny's own career indicates that the dividing line between "author" and "journalist" is anything but clear, as the study of any number of contemporary and modern writers, from Émile Zola to Gore Vidal, will show. De Montigny is often described in the pages of the AJCF's press campaign along the lines of "un journaliste canadien-français, doublé d'un littérateur distingué." 9 The period in which de Montigny worked is known to be one of transition from a literary to a more industrial, news-based journalism; still, vestiges of the former approach are apparent in Vidal's example. ${ }^{\text {IO }}$

The role of the daily newspaper has been underestimated in establishing enumerative author bibliographies and literary canons. ${ }^{\text {II }}$ At the time of the AJCF's campaign, the ephemeral format of newspapers as opposed to books or even to magazines, along with newspapers' perceived information and publicity value, justified the free reprinting of copy, edited at will, for the popular "feuilleton" or serialized fiction feature. Not even the 1906 decision could stop the

7 See Josée Vincent, "Un premier regroupement 'professionnel' d'écrivains au Québec: la section française de la Canadian Authors Association (I92I-I936)," in Lieux et réseaux de sociabilité littéraire au Québec, ed. Pierre Rajotte (Quebec: Éditions Nota bene, 200I), 275-333.

8 The Act to Amend the Copyright Act received royal assent in 1900; it strengthened the market position of Canadian authorized reprint editions of British works. See Parker, 253-56.

9 See Jean Lionnet's "Seize ans de piraterie" in Le Soleil [Paris], 7 May 1904.

Io Josée Vincent cites literary historian Lucie Robert: "devenu profession, le journalisme se transforme et perd ses caracteristiques littéraires." See Vincent, 283. 
practice, which was well entrenched and difficult to enforce, because authors' names and titles of their works continued to be altered or omitted from their novels when edited or translated for serialization, all for competitive rather than intentionally larcenous reasons. The point is that the phenomenon of literary counterfeiting was a complex one, not restricted to books, and one that had no blanket solution. Rather than deplore the pirates, Michon invites us to consider their transitional role in opening new markets of readers. Journalists were at the centre of this in that the newspaper presses helped to develop the financial and technical infrastructures needed for a growing and varied print culture. ${ }^{12}$ Similarly, by legitimizing their profession and challenging the piracy taking place in the press and in book publishing, the journalists of the AJCF caused the tidewaters of public awareness to rise, and so were able to raise all boats and do good for all types of writers.

\section{The Press Campaign}

In March of 1903, the Chambre de Commerce française de Montréal (a branch of a Paris organisation with offices around the world) sounded the alarm in its bulletin about the piracy of French authors' works in Canada. In the autumn, Ovide Robillard, a lawyer representing the Société des gens de lettres de France, spoke before the American Chamber of Commerce in Paris about a similar state of affairs in the United States (further proof of Parker's view that British authors had been more vigilant than the French in challenging literary piracy in North America). After reading these and other accounts of the problem, de Montigny decided to bring together the various complaints and present the legal facts that likely would lead to a solution. Under the pseudonym (for reasons unclear) of "Florandeau," on 29 November 1903, on the front page of Le Canada économique, financier, minier et industriel, a Paris weekly newspaper supporting Canadian-French investment and trade, he reinforced the argument that it was time to take the issue out of the realm of culture and letters and to pursue it as a matter of trade and commerce. In this regard,

II See Charles Johanningsmeier, Fiction and the American Literary Marketplace: The Role of Newspaper Syndicates, 1860-1900 (Cambridge: Cambridge University Press, 1997).

I2 See Jacques Michon, "Contrefaçon littéraire et développement culturel," Revue de bibliologie, schéma et schématisation 34 (1991): 38-44. 
de Montigny's astute choice of publishing venues for the campaign is evident throughout. The other main thrust of the campaign besides the monetary concern is the link between ending piracy and encouraging indigenous writers. The point is made early on, in a short, unsigned article subtitled, "Protégeons ceux qui travaillent," that had appeared in La Patrie, the liberal Montreal daily, nine days before the piece in Le Canada économique. With these, the international campaign was launched.

De Montigny realized that conditions would not improve for French-Canadian authors until the precedence of the Berne Convention over the Canadian Act was established. He seized the key legal concept that the challenge could not be mounted by Canadian authors who suffered indirectly from the unfair competition of unauthorized reprints, for no Canadian or Imperial law was being broken when Canadian publishers preferred not to print their works at all. The rights of published Canadian authors under Berne applied only outside Canada. It followed, then, that reclamations under the Imperial law would have to originate with the French authors whose rights were being abused. Little time was wasted getting the Sociéte des gens de lettres on board. In Paris, on 2r December 1903, the Society heard a report encouraging multilateral collaboration presented by Edmond Montet, the editor of the Le Canada économique, and by Jean Lionnet, author and member of the Society as well as president of the Canadian-French organization La Canadienne of Paris. ${ }^{{ }^{13}}$ The Canadienne association reported on the meeting in its monthly Bulletin de La Canadienne in March 1904. The Bulletin's account demonstrates the value of the collected articles of the AJCF's press campaign. Like many of the other contributions to the discussion, it not only outlines the issues, but identifies the parties involved and describes their interactions. Many opinions are quoted directly. Seven articles in all, which followed closely the campaign's progress, appeared in that organ during 1904. On 7 May 1904, an article by Lionnet, "Seize ans de piraterie," appeared in the Paris daily, Le Soleil. In it, Lionnet praises the emerging literature of French Canada and condemns the unfair competition of pirated French plays, novels, and poems in theatres, newspapers, and books, giving numerous

I3 The interests of La Canadienne may be inferred by reading its roster of directors: honorary presidents of the association in 1903 were the Canadian trade envoy to France, a senior departmental councillor, and the legislative assembly member for Paris. The executive board included "man of letters" Lionnet, professors, lawyers, and the Treasury inspector. 
examples. De Montigny is quoted on the subject of other legal opinions he gathered on the validity of the Berne Convention in Canada. He reports that the precedence of Berne over the Canadian Act is considered indisputable, and that in spite of this, the piracy not only continues, but is defended even when challenged. French playwright Émile Bergerat's letter claiming royalties for performances of his play, Plus que reine, addressed to Paul Cazeneuve, the director of the Théâtre national français of Montreal, was rebuffed thus: "Je n'ai nullement volé votre pièce, la brochure ayant été achetée à Paris.... Les droits d'auteur n'existent pas au Canada." Certain that the "Convention suisse" lacked authority, the impresario then threatened to sue Bergerat for libel! Writing in Paris, Lionnet deplores the French attitude that allowed the piracy to have continued for so long: "En vérité, nous sommes le peuple le plus débonnaire du monde."

In Montreal, the Bulletin de la Chambre de Commerce française had printed in full the two letters of Bergerat and Cazeneuve in January 1904, with a short preamble, under the heading "Droits d'auteur," with a follow-up piece in March. ${ }^{14}$ The AJCF's campaign had progressed by August, when the Bulletin de la CCfM printed full legal attestations of the AJCF's legal team now officially on board, Geoffrion, Geoffrion \& Cusson, as well as a letter to de Montigny supporting the pro-Berne view from J.B. Jackson, the legal clerk of the Copyright and Trademarks section of the Ministry of Agriculture in Ottawa. In October, the Bulletin de la CCFM reprinted a lengthy exchange which had appeared in the Montreal weekly, Le Nationaliste, between de Montigny and Georges Gauvreau, founder of the Thêatre national, who presumably was in a senior position to Mr. Cazeneuve. In a deft piece of damage control, Gauvreau expresses glowing confidence in the future of French-Canadian letters, praises local playwrights, and regrets the hardships they face. As a businessman, however, he still wants it both ways: he invokes the I875 Canadian Act in order to defend his right to present French plays without paying royalties, until such time as the matter is settled in court.

Also in late 1903 and throughout 1904, La Presse, the largest of the Montreal dailies, ran at least a dozen unsigned articles chronicling the AJCF campaign and arguing on its side under such titles as "Les droits des auteurs étrangers au Canada." Other articles appeared in the daily Le Canada [Montreal], in La Vérité [Quebec City], in L'Album

I4 The Bulletin was the monthly publication of the Chambre de commerce française de Montréal. In its eleventh year in 1904, it had a circulation of 1,000 . 
universel (Fig.1) and Le Passe-temps [Montreal], and at least two more in La Patrie. In Paris, additional sporadic coverage was provided by Le Courrier européen, La France de demain, Le Journal des débats, L'Informateur des gens de lettres, La Revue bleue, and La Revue des revues. On 6 March 1904, de Montigny's collaborator on Les Débats, Olivar Asselin, published the first issue of Le Nationaliste, the political Montreal weekly which would be an ardent champion of the AJCF's cause. More than a dozen articles appeared in the Nationaliste by the end of the year, most of them signed by de Montigny, covering various developments in the copyright struggle, one being the tribulations of Charles ab der Halden, the French author of Etudes de littérature canadienne française. ${ }^{\text {I5 }}$ Hoping to protect Canadian sales of his Paris edition, ab der Halden and his publisher registered it in Ottawa, depositing two copies with the Ministry of Agriculture and printing a notice of the registration on the book's endpaper, so far in accordance with the Canadian Act. They relied on the Berne Convention to guarantee their rights the rest of the way. Immediately after the edition went on sale, they were notified by the Ministry that they were in violation of the Canadian Act for failing to reprint the work in Canada. The endpaper notices had to be covered up. Furthermore, in the case that a Canadian wanted to publish an edition (and pay no royalties, of course), subsequent importation attempts and sales of ab der Halden's editions would become contraband transactions; a Canadian competitor could take him to court and have him fined $\$ 300$, of which the Canadian would be entitled to half. No Canadian edition appears to have been produced. ${ }^{16}$ Library copies of Études de littérature canadienne française consulted for this article lacked the original covers and endpapers and did not include this bibliographical anomaly. The hunt continues for a copy in original condition, as well as for a copy of Hubert's edition of Tante berceuse.

In the AJCF's assembled articles, the lack of duplication is striking. One expects to find some duplication of articles or repetition of their content, but it is a sign of de Montigny's dedication to the principle he was arguing, namely that intellectual product is property, that

I5 Charles ab der Halden, Études de littérature canadienne française, introd. par Louis Herbette, "La Langue et la littérature françaises au Canada, la famille française et la nation canadienne"(Paris: Rudeval, 1904).

I6 See ab der Halden's ardent dedication to Louvigny de Montigny in the sequel to this work, Nouvelles études de littérature canadienne française (Paris: Rudeval, 1907). 


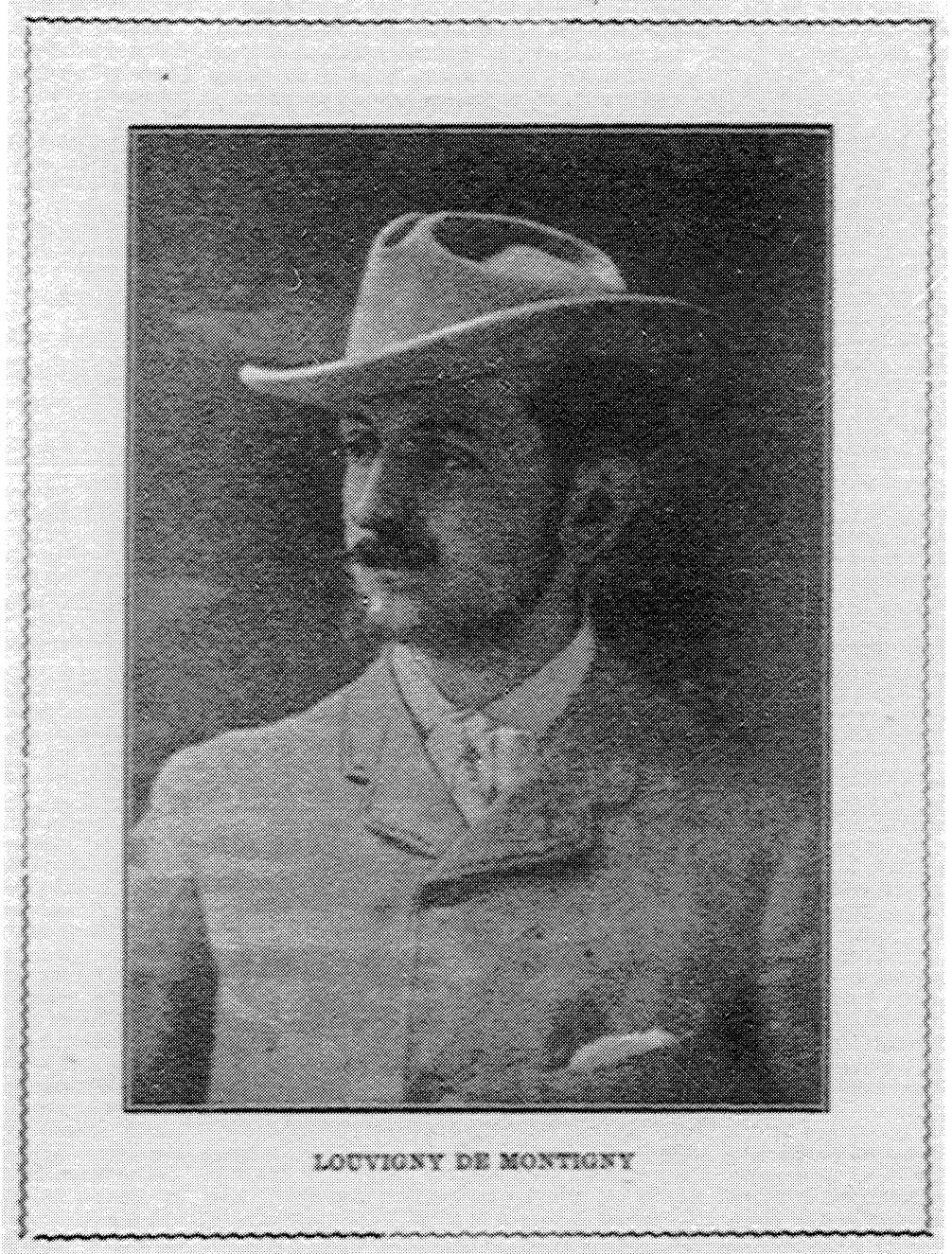

Figure I. Album universel 19, No. 43, p. IoI3, reproduced from a copy held in the collection of University of Toronto Libraries. 
each article is unique. Certainly, some elements recur in the articles, and certain correspondence and legal opinions are repeated verbatim, but each article is edited anew, much to de Montigny's credit. Two dissenting editorial pieces have been discovered so far: the conservative Montreal daily, Le Journal, weighed in on I August 1904, expressing doubt that an idea, mere air and smoke after all, could be owned exclusively as one might own a piece of land. The anonymous contributor quotes the French critic Sainte-Beuve in conversation with Flaubert: "La pensée, c'est de l'air, de la fumée. Un auteur écrit pour être lu, et il doit être trop heureux qu'on le lise. Il devrait dire à tout le monde: Prenez, prenez! $!^{17}$ The Journal writer agrees with de Montigny that books should be protected against piracy, but that newspapers should be allowed to reprint freely, for the benefit of readers and authors alike. Citing again the public good, he scores a hit against de Montigny, without giving the name, claiming that if theatres had to pay royalties for French "masterpieces," they would be reduced to presenting works the likes of de Montigny's Les boules de neige. In his opinion, Canadian authors and playwrights would simply need to create masterpieces in order to compete with the French. The next issue of the Nationaliste carried a response in the form of a question: if Canadian authors brought masterpieces to the Journal, would the paper begin to respect the work of Canadian and French authors alike by stopping its reliance on free material for its feuilleton in order to fill its empty pages? The Journal stands accused of omitting fiction titles, chopping scenes, and hiding the names of the authors of these "borrowed" works. The next day, 8 August 1904, the Journal gets in the last word: "Le Canada est encore dans l'enfance de la littérature." The editorialist denies calling for Canadian masterpieces. He says he would settle for anything readable, but he immediately contradicts himself by stating that if he did have to pay for works for his feuilleton, he would still prefer the French product, a Canadian masterpiece being a remote possibility in any case. In a variation of the public-good argument, he suggests that young Canadian authors should study his feuilleton section to learn what good writing is.

On I December 1904, the Union of Artistic and Literary Societies of France voted to mount a test case in Canada. ${ }^{18}$ Asselin voiced

17 "Protection: Les Droits d'auteur," Le Journal [Montreal] I Aug. 1904: 4.

I8 The Union, Le Syndicat des sociétés artistiques et littéraires pour la protection de la propriété intellectuelle, included fifteen groups of authors, composers, artists, architects, inventors, photographers, and the like, including the Société des gens de lettres de France. 
his support in the Nationaliste: "Tirez les premiers, Messieurs les [F] rançais: Nous tirerons ensuite ... avec vous." Three detailed and authoritative articles that had appeared in Le Droit d'auteur, the official organ of WIPO's predecessor, the International Copyright Union - United International Bureaux for the Protection of Intellectual Property, in Geneva, certainly influenced the crucial decision. The June 1904 number alone devoted four pages to Canada and the international copyright question.

Towards the end of 1904, the copyright question, the international collaboration, and the legal test case could finally be described in depth and presented in Canada's most prestigious literary and topical monthly, La Revue canadienne. ${ }^{19}$ The sub-corpus of six articles, spanning a period of nineteen months, provides an exhaustive, lasting document of the AJCF's campaign and its legacy. In October 1904, in "La contrefaçon littéraire au Canada," de Montigny set out the need for reform. In January 1905, Louvigny de Montigny was thinking of posterity when he published, under the quill-and-inkwell logo of the AJCF, "La fin du pillage des auteurs: documents pour servir à l'histoire des lettres et du journalisme au Canada" (Fig. 2). The October 1904 and the January 1905 articles have been widely cited elsewhere, providing as they do a superb resumé of the copyright question, of tariffs and market conditions, of the international collaboration, of the legal arguments, and of the campaign. ${ }^{20}$ Also in the Revue canadienne, in March 1905, Auguste Dorchain (of the Société des gens de lettres) revisited the subject of French financial losses and the Canadian tariffs which created the uneven playing field between Toronto and Montreal publishers, to which we shall return shortly. ${ }^{21}$ Mary vs. Hubert was prepared during 1905 and submitted to the Montreal District of Quebec Superior Court on I2 January $1906 .^{22}$ The coverage resumed: the victory of 23 March

19 See Michon (1999), 396-99.

20 La Revue canadienne (Oct. 1904): 422-33; (Jan. 1905): 67-82.

2I Louvigny de Montigny was to have provided a similar article for the February issue, but he was recovering from a "serious illness," according to the editor's note. Dorchain's article had just appeared in a new Paris weekly called Énergie française, and was reprinted in the Revue, with the author's permission.

22 Little is known about Barthélémy Hubert. Some sympathetic publishers, including the top firm, Beauchemin, and Jules Hellbronner of La Presse, offered themselves up for the court challenge, as they, too, were eager to see an end to the uncertainty that plagued their operations by supporting unfair competition. The name of Mr. Hubert's obscure firm, La Compagnie générale de reproduction littéraire, may provide some insight into the choice of defendant, about whom information is oddly lacking in the otherwise detailed articles about the affair. 


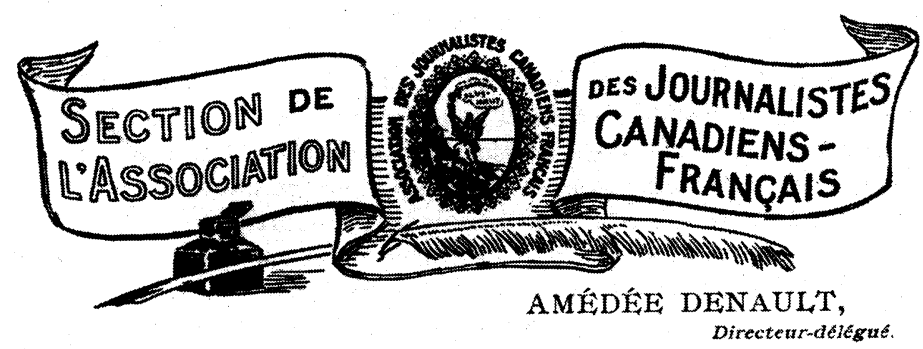

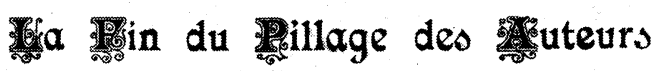

DOCUMENTS POUR SERVIR A L'HISTOIRE DES LETTRES ET DU JOURNALISME AU CANADA.

La campagne entreprise en juillet dernier par l'Association des Journalistes, en vue d'obtenir la réglementation des droits d'auteur au Canada, promet de se terminer très prochainement par une victoire éclatante; et cette victoire sera d'autant plus belle qu'elle mettra fin à un abus sous l'énormité duquel la littérature canadienne-française se sent écrasée.

Notre Association pourra à bon droit se féliciter, pour ses débuts, d'avoir réussi à amener les autenrs de France à faire reconnaitre au Canada les droits de la propriété intellectuelle, de la nôtre comme de la leur; notre Association pourra se féliciter de cette action patriotique dans le plus beau sens du mot et la moins vide expression du sentiment.

Si des semaines et même des mois ont passé sans que nous entretenions nos lecteurs des progrès de notre campagne, on ne doit pas en conclure que se soient lassés nos camarades chargés

Figure 2. La Revue canadienne (Jan. 1905), p. 67, reproduced from a copy held in the collection of the University of Toronto Libraries. 
1906 was eagerly anticipated in a full account of the plaintiffs and the defendant's arguments in the March 1906 issue of the Revue canadienne. The May issue contains the full account of Judge Fortin's verdict, as well as the plaintiff s legal response to the defence. Finally, in the same issue, de Montigny's friend and colleague Albert Laberge wrote "Maintenant, travaillons!" The article carries photographs of de Montigny, Lionnet, Dorchain, ab der Halden, Judge Fortin, and lawyers Édouard Sauvel, Aimé Geoffrion, and Pierre Beullac, and praises their individual contributions and their collaboration. The verdict was announced in April 1906 in the Bulletin de la Canadienne, and elsewhere: "Tous les littérateurs, des deux côtés de l'Atlantique, salueront avec joie cette victoire."

\section{The Problem of Canadian Customs Duties on French Books}

In the deceptively light and entertaining interview style that was popular at the time, de Montigny's informative October 1904 article in the Revue canadienne, "La contrefaçon littéraire," unfolds the complex dynamic of tariffs and book-production norms which shaped market conditions for French-Canadian publishers and booksellers. De Montigny's well-informed interlocutor is Étienne Roby, a director with 32 years' service at Librairie Beauchemin, the Montreal publisher and retailer. According to Roby, Canadian copyright legislation was drafted with only the needs of the English-language industry in mind. First of all, the 1875 Act Respecting Copyright, as it stood in 1904, did not provide for translations. In that it went to such extremes to ensure the supremacy of a single Canadian edition of a given work in the marketplace is one reason the Act is generally considered today to have been flawed. (To regard translations as competing editions within Canada does seem especially anglocentric.) Roby gives the example of George N. Morang's Canadian edition, in English, of the Polish novel Quo Vadis: by law, it precluded all other editions, domestic and foreign, in any language. French Canadians were only able to enjoy the book in their own language thanks to a concession Morang was kind enough to offer Beauchemin: copies of the translation Beauchemin had ordered from France were stopped at customs until Morang had them released.

Canadian import duties had been adjusted in 1897 to $10 \%$ on hardbound books and $20 \%$ on soft-cover books. ${ }^{23}$ Designed to inhibit

See Parker, 245-46. 
the spread of cheap novels from the United States, so that Canadian publishers could compete at home with their own cheap novels, the lower 10\% tariff applied to all hard-bound books (and some softcover books, as we shall see). British and American textbooks and other volumes that were considered useful or educational, such as works of "serious" literature, were normally produced in hard-bound editions. French imports, however, due to inherent differences in industry norms, were almost entirely soft-cover editions, and therefore subject to the higher $20 \%$ tariff rate. With the addition of royalties paid to French authors and overseas shipping costs, a novel that typically retailed for 3.50 francs in Paris would need to be marked up to 90 cents, or about 4.32 francs, by the time it was legitimately imported to Montreal or Quebec City and sold in accordance with Berne requirements. At the time, a similar Canadian edition sold for 20 or even to cents. Furthermore, Roby confirms that a clause of the Canadian tariff regulation distinguished between fiction and non-fiction books within the soft-cover category; the lower I0\% rate for soft-cover, non-fiction titles encouraged the importation of such "nonsense" as La Cartomancie and La Clef des songes over the fiction works of the great authors, and thus did a further disservice to French-Canadian readers.

Publishing in French was not an impediment to cheap competing imports from the U.S. Roby mentions the Jenkins firm of New York by name and alludes to dozens of other American firms that were equipped to supply growing French-reading markets in the U.S. and Canada. Unauthorized reprinting was often the only choice for Montreal firms, and for reasons other than the obvious financial pressure. Librairie Beauchemin, for example, felt compelled to produce an unauthorized edition of Rostand's Cyrano de Bergerac. The Jenkins (American) reprint was flying off their competitors' shelves at a fraction of the price of the original French edition by Fasquelle stocked by Beauchemin, so the Beauchemin directors felt justified competing with it. They could do so profitably, having a $20 \%$ advantage over the American import. Had Beauchemin registered its edition in Ottawa, however, in order to drive out the American edition, it might have been able to keep the price relatively low and still pay authors' royalties (even though Canadian law did not require it), but its registered edition would have precluded subsequent importation of the French edition, turning the original into contraband. As things stood, the Beauchemin firm regretted that the American competition prevented its paying royalties (despite the $20 \%$ advantage, curiously). 
What's more, in order to protect the status of the original, it had to continue to tolerate the American competition, the very problem the I897 tariffs were in place to redress. Beauchemin's Canadian edition, then, had to remain an illegal reprint of the "lovely" Fasquelle edition of Cyrano. A comparison of the Fasquelle with the much smaller, cheaper Beauchemin and Jenkins editions confirms at a glance why readers who preferred to enjoy the original edition should indeed have been grateful it was not driven out by a registered Canadian reprint. Roby's exasperation is apparent: "Voilà nos lois!"

\section{Conclusion}

Canada's observance of the Berne Convention had the potential to address many of the problems outlined above by diminishing the influence of the Canadian Copyright Act on French-Canadian authors, publishers, and retailers. It is not surprising that the establishment of Berne's legitimacy in Canada was due to the efforts of French Canadians. English-Canadian publishers and booksellers had little motivation, to say the least, to support authors' reform efforts, unlike their counterparts in Quebec. Nor did British authors need the Berne Convention in order to solve their remaining copyright problems in Canada. Even though they were obliged to compromise with Canadian publishers seeking manufacturing protection, their interests were already being promoted through official channels to the maximum extent possible. For French authors, the success of Mary vs. Hubert established their right to payment for their works reproduced or sold in Canada. The unfavourable Canadian tariff levels on their books remained in place for thirty years, but the problem of proliferating, cheap, competing editions impeding the choice between the importation of an original edition and the production of a decent Canadian edition was alleviated. Unauthorized American reprints of works of any origin no longer needed to be tolerated in Canada, as Berne member countries had the power to seize illegal editions on behalf of other members.

Most of the information presented here has been gleaned from the pages of the AJCF's press campaign; the value of the contemporary accounts and opinions is clear. The campaign took place at an important point in time for Canadian letters, when English- and French-Canadian writers, both authors and journalists, struggled to establish cultural and professional autonomy. It is impossible to say exactly when and how our national literatures "emerged," but the 
Mary vs. Hubert decision must have been a turning point in the process, probably more on the French than the English side. Certainly the initiative to form the AJCF in 1903 was influential. Having the blessing of a French-Canadian Prime Minister, Wilfred Laurier, who was a former journalist, certainly helped the AJCF to legitimize its claims and redress the disparity in book-trade practices in the two parts of the country. The link between the AJCF and the authors' associations created in $192 \mathrm{I}$ is evident. The birth of those societies coincides with the reform of the Copyright Act that had been necessary for so long. The Mary vs. Hubert challenge, although it seemed primarily to benefit foreign authors, was an important step for a modern, viable industry of letters to evolve in twentieth-century Quebec: not only did the mitigation of unfair competition stabilize commercial conditions, but, more importantly, French-Canadian authors gained access, which had been severely limited by piracy, to their own marketplace. The ideal of a French-language national literature in Canada, already in the public consciousness, would gain, through Mary vs. Hubert, the level playing field it needed to become an overriding reality.

\section{SOMMAIRE}

Le précédent de la jurisprudence qui établit la Convention internationale de Berne sur la propriété intellectuelle comme étant la loi sur le droit d'auteur qui allait prédominer au Canada, fut le résultat de la cause Mary versus Hubert, une poursuite judiciaire entendue à la Cour supérieure du Québec le 23 mars 1906. La décision en faveur de l'auteur parisien Jules Mary donna préséance à la Loi sur le droit d'auteur international de 1886 , la loi impériale qui amena la Grande-Bretagne et les pays membres du Commonwealth à la Convention de Berne, sur la Loi canadienne concernant le droit d'auteur de I875. Depuis I886, les deux lois étaient en vigueur en même temps, mais la perception voulue et erronée des éditeurs et des détaillants de leur valeur respective permit aux pratiques de piraterie littéraire de persister au Québec, après qu'elles aient diminué dans le reste de l'Amérique du Nord. Le dénouement heureux pour le demandeur, une victoire pour les auteurs, fut le résultat d'une campagne intense de sensibilisation du public, menée dans divers périodiques des deux côtés de l'Atlantique par Louvigny de Montigny de Montréal et par ses collègues de l'Association de secours mutuels des journalistes canadiens français (AJCF). De Montigny et l'AJCF 
non seulement persuadèrent des auteurs en France de monter une cause type au Canada, mais ils s'assurèrent que la contestation allait être considérée par des cabinets d'avocats canadiens et par la cour. Le statut du Canada en tant que pays membre du Commonwealth garantissait déjà les droits des auteurs britanniques, mais les œuvres littéraires de la France n'avaient pas plus d'importance sous la loi canadienne que les œuvres provenant des autres cultures, considérées légitimement comme étrangères. Aggravant la situation, les tarifs douaniers incorporés dans la loi canadienne protégeaient le marché canadien anglais contre les réimpressions américaines, mais ils étaient nuisibles pour les importateurs canadiens français qui devaient tenir compte de normes de production différentes en ce qui a trait au livre. Les historiens du livre reconnaitront le lien existant entre la forme matérielle des livres et les conditions législatives, ainsi que celles du marché, gouvernant leur production et leur distribution.

La description de ces conditions par Jacques Michon, ainsi que de la campagne de presse transatlantique de l'AJCF, a permis de susciter un intérêt bibliographique dans l'assemblage d'un corpus d'articles. La compilation présentée ici, laquelle comprend quelque soixante-dix documents photocopiés, de tailles et de tons divers, est étonnante en termes de l'ampleur et de la profondeur du traitement des difficultés concernant le droit d'auteur et les tarifs au Canada français d'avant 1906, ainsi que de la création et de la campagne de presse de l'AJCF. Cette petite collection d'archives fait l'objet d'une collaboration permanente entre les chercheurs du Joseph Sablé Centre for 19th Century French Studies à l'Université de Toronto et le Groupe de recherche sur l'édition littéraire au Québec (GRÉLQ) de l'Université de Sherbrooke. Cet article a pour but de jeter un peu de lumière sur la différence entre les deux marchés du livre canadiens régis avant 1906 par une seule Loi canadienne sur le droit d'auteur. En présentant la campagne de de Montigny dans la presse, on espère que la richesse des renseignements contenus dans ces documents de l'époque donnera de l'ampleur aux données existantes et montrera un exemple où les deux solitudes de nos histoires nationales de l'édition non seulement s'entrecroisent, mais aussi interagissent : plusieurs des problèmes concernant l'importation et la réimpression auxquels les éditeurs montréalais continuaient de faire face bien après 1886 , étaient le résultat direct de l'influence politique des éditeurs de Toronto sur les lois fédérales portant sur les tarifs et le droit d'auteur.

La cause Mary versus Hubert, bien qu'elle semblait d'abord profiter aux auteurs étrangers, constitua une étape importante permettant 
à une industrie des lettres moderne et viable d'évoluer au Québec, au vingtième siècle : non seulement la réduction d'une compétition injuste stabilisa les conditions commerciales, mais, ce qui est plus important encore, les auteurs canadiens français eurent accès à leur propre marché, lequel avait été sévèrement limité par la piraterie. L'idéal d'une littérature nationale de langue française, présent déjà dans la conscience publique, allait bénéficier, au moyen de Mary versus Hubert, de règles du jeu équitables nécessaires pour devenir une réalité qui allait l'emporter sur toutes les autres. 